\title{
Plant responses to pine management and deferred-rotation grazing in north Florida
}

\author{
CLIFFORD E. LEWIS, GEORGE W. TANNER, AND W. STEPHEN TERRY
}

\begin{abstract}
Responses of herbaceous and woody plants to combinations of 4 pine management and 4 graxing management systems were tested on a wet-flatwoods site in the pine-wiregrass vegetation type of north Florida. Frequency of occurrence of herbaceous species and foliar cover of woody species were determined in natural stands of 50-year-old slash and longleaf pine (Pinus elliottii Engelm. and $P$. palustris Mill.) and compared to similar forest sites that were harvested and site prepared by double-chopping and not replanted with slash pine, or replanted to 1,112 trees/ha in single- and double-row configurations. In addition, these sites were ungrazed or grazed using 3 deferred-rotation systems. Prescribed burning in the natural stands increased occurrence of most herbs and stimulated new species to occur, but had little effect on woody plant composition. However, harvesting of pines and double-chopping resulted in the occurrence of many new herbaceous species and increased occurrence of most initially present. Pineland threeawn (Aristida stricta Michx.), the major herb, initially decreased in occurrence with intensive site disturbance. Six years after disturbance, most herbaceous species were declining in occurrence. Grazing or growth of replanted pines had little influence on occurrence of herbaceous species. Both burning and mechanical disturbances initially reduced foliar ground cover of most woody species; however, few species were eliminated from the community. Most woody species were recovering within $6 \mathrm{yr}$ from treatment, but succession was somewhat slower on mechanically treated areas. Survival and growth of planted pines were not affected by grazing, nor did planting configuration affect pine growth.
\end{abstract}

Key Words: pine-wiregrass vegetation, succession, mechanical site disturbance, prescribed burning

Management for simultaneous production of 2 or more products often creates conflicts and competition. Intensive site preparation and forest management practices in the South affect all components of an ecosystem since both overstory and understory vegetation are manipulated by harvesting, site preparing, and planting density. At the same time, use of livestock to harvest native forages also can affect a number of resources. Research on single-product management has yielded little information about long-term effects of intensive timber or range management on each other or other forest resources. Several attempts have been made to synthesize the fragmented literature into evaluations of multipleuse management (Lewis 1973, 1975, 1977; Pearson 1975, 1980), but these attempts do not replace the need for actual research involving multiple-use objectives. Past research has shown that intensity and season of grazing affects planted pine survival along with production and species composition of the forage resources (Halls et al. 1956, Hilmon et al. 1962, Pearson et al. 1971). Also, tree planting density, thinning practices, and length of timber rotations greatly affect understory plants for livestock and wildlife use (Grelen et al. 1972, Lewis 1975, Pearson 1980, Wolters 1982). Deferred-rotation grazing is reputed to improve forage conditions, but has not been tested in pine-wiregrass vegetation.

\footnotetext{
Authors are range scientist, USDA-Forest Service, associate professor, and range research biologist (formerly), Department of Wildlife and Range Sciences, University of Florida, Gainesville 32611. Terry is currently land resources manager, Miccosukee Indian Reservation, Miami, Florida 33144.

Manuscript accepted 24 May 1988.
}

This study was designed to test 2 general hypotheses. First, understory species' frequency of occurrence and woody species foliar cover are not altered by 4 timber management treatments. Secondly, implementation of 3 deferred-rotation grazing systems among the timber management treatments will not affect herbaceous species, woody species, and planted pine responses. We are reporting the responses of herbaceous and woody vegetation to this intensive type of multiple-use management.

\section{Methods}

\section{Study Area}

The experimental area was located on 73 ha of the University of Florida's Austin Cary Memorial Forest, Alachua County, Florida, on a typical flatwoods site of the pine-wiregrass vegetation type. The area originally was occupied by a natural stand of 50-year-old slash (Pinus elliottii Engelm.) and longleaf pine ( $P$. palustris Mill.) with a basal area of $20.7 \mathrm{~m}^{2}$ per ha. The area had been protected from fire and other disturbances for many years until it was lightly prescribed burned during the winter of 1975-76.

The climate of this area typically is subtropical and humid with long, hot summers and short, mild winters. The frost-free period averages 276 days. Rainfall averages about $140 \mathrm{~cm}$ per year, with about half falling during June through September.

Soil on about $70 \%$ of the experimental area is a sandy, siliceous, hyperthermic Ultic Haplaquod of the Pamona series, which is acid and contains an organic stain layer between 41 and $61 \mathrm{~cm}$, with a clay layer at about $109 \mathrm{~cm}$. Basinger fine sand (a siliceous, hyperthermic Spodic Psammaquent) occurs at slightly lower elevations and occupies about 15\% of the area. Sparr sand (a loamy, siliceous, hyperthermic Grossarenic Paleudult) and Adamsville sand (a hyperthermic, uncoated Aquic Quartzipsamment) occurs at slightly higher elevations on the remaining $15 \%$ of the area.

Twenty-eight 1-ha test pastures were selected for timber and grazing treatments. The remaining area was divided into 3 holding units for cattle when they were not grazing the test pastures. Twenty-two test pastures and the holding units were clearcut during the fall and winter of 1976-77, then were double-chopped with a roller-drum chopper during August and September 1977. As is typically done in grazed forests of the South, the 6 pastures left in natural stands were prescribed burned with fairly hot back-fires during February 1978 and again in February 1981. A deer-proof fence was built around the entire 73-ha study area in the fall of 1977 and 5 white-tailed deer (Odocoileus virginianus Zimmerman) were placed on the area. Slash pine was planted during the winter of 1977-78. Interior pasture fences were built in the summer of 1978 . Cattle were placed on the area in March 1979 and grazed in test pastures from May 1979 until the study was discontinued in December 1983.

\section{Treatments}

The study was a factorial experiment of 4 timber treatments and 4 grazing treatments in which 2 treatment combinations were not used (Table 1) in a randomized complete-block design with 2 blocks. One block was somewhat drier than the other. Timber treatments were: (1) natural stands of 50-year-old pines; (2) clearcut, chop, no planting of pines (open); (3) clearcut, chop, plant slash pine ( 1,112 trees $/$ ha) at a spacing of $2.4 \times 3.7 \mathrm{~m}$ (single rows); 
Table 1. Combinations of 4 timber conditions and 4 grazing conditions contained in the factorial experiment on the Austin Cary Memorial Forest.

\begin{tabular}{|c|c|c|c|c|c|}
\hline \multirow[b]{2}{*}{$\begin{array}{l}\text { Timber } \\
\text { treatments }\end{array}$} & \multicolumn{5}{|c|}{ Grazing treatments } \\
\hline & $\begin{array}{l}\text { Graze (days) } \\
\text { rest (months) }\end{array}$ & $\begin{array}{r}0 \\
12\end{array}$ & $\begin{array}{r}45 \\
3\end{array}$ & $\begin{array}{r}30 \\
4\end{array}$ & $\begin{array}{r}30 \\
6\end{array}$ \\
\hline \multirow{4}{*}{\multicolumn{2}{|c|}{$\begin{array}{l}\text { Natural stand, } 50 \text { yr old pines } \\
\text { Site prep only- no pines planted } \\
\text { Site prep, single-row pines }-2.4 \times 3.7 \mathrm{~m} \\
\text { Site prep, double-row pines- } \\
\quad(1.2 \times 2.4) 12.2 \mathrm{~m}\end{array}$}} & $\mathbf{x}$ & & $x$ & $x$ \\
\hline & & $\mathbf{x}$ & $\mathbf{x}$ & $\mathbf{x}$ & \\
\hline & & $\dot{x}$ & $x$ & $\mathbf{x}$ & $\mathbf{x}$ \\
\hline & & $\mathbf{x}$ & $\mathbf{x}$. & $\mathbf{x}$ & $\mathbf{x}$ \\
\hline
\end{tabular}

and (4) clearcut, chop, plant slash pine $(1,112$ trees / ha $)$ in a doublerow configuration at $1.2 \times 2.4 \mathrm{~m}$, with $12.2 \mathrm{~m}$ between double rows. Slash pine seedlings were from genetically selected seed that were nursery grown for about 1 yr. Grazing treatments compared no-grazing with 3 deferred-rotation systems: (1) graze 45 days then rest the pasture for 3 months before grazing again; (2) graze 30 days with 4 months rest; and (3) graze 30 days with 6 months rest. The 14 treatment combinations were randomly located in each block.

We used 2 herds of beef cows in a put-take system to simulate the grazing treatments. The overall objective was to remove about $50 \%$ of the available forage during each grazing period. About 5 animals were placed in a pasture at the beginning of a period for a short time ( 2 or 3 days) then removed for several days. This would be repeated throughout a prescribed grazing period in an effort to simulate the type of use that forage plants usually receive as cattle move through an area and periodically graze the same location or plants. Under this system the cattle were used only to impose grazing treatments on the vegetation and not as measures of animal responses to treatments.

\section{Measurements}

Three 30.5-m line transects were randomly placed in each test pasture at $45^{\circ}$ angles to the tree row orientation. To determine herbaceous species frequency of occurrence, each transect was divided into $10030.5-\mathrm{cm}$ segments. A species was tallied as present if any living part of the plant intercepted the transect. Results are expressed as frequency of occurrence per $30.5-\mathrm{m}$ transect. Crown intercepts of all woody vegetation were measured to the nearest centimeter by species along the line transect. Plant measurements were made in 1976 before treatment and subsequently in the fall of 1978, 1980, 1981, and 1983.

Tree survival and growth was determined in each planted pasture by measuring 10 trees permanently located near the center of each line transect. Total height, stem diameter, height to crown, diameter of crown, mortality, and damage by animal, disease, or insect were determined annually.

\section{Statistical Analyses}

Significance in analyses of variance was determined at the 0.05 level. Single degree-of freedom contrasts tested for significance in the timber treatments were natural tree stands vs. harvested/ chopped, chopped/not planted, vs. chopped/planted, and singlerow vs. double row configurations. Grazing treatments were tested for: ungrazed vs. grazed, 45-day grazed vs. both 30-day grazed treatments, and $30-4$ vs. 30-6 grazing.

Statistical analyses of the data showed that most of the significant differences in timber treatments were between the natural tree stands and the clearcut and site prepared stands. Most of the significant differences due to grazing treatments were between ungrazed and grazed conditions. Therefore, the data were combined for ungrazed and grazed treatments from both natural tree pastures and mechanically disturbed pastures. Of the $142 \mathrm{herb}$ and 68 woody plants encountered, species presented are those having significant differences, being prevalent in most treatments, show- ing important trends, or being important cattle or wildlife foods.

\section{Results and Discussion}

\section{Natural Tree Stands \\ Woody Plants}

Cattle grazing had no significant impact on woody plant species in the natural tree stands (Table 3). It was apparent that species, such as saw-palmetto [Sereno repens (Bartr.) Small], gallberry [Ilex glabra (L.) A. Gray], and other shrubs that had dense stands initially tended to maintain this condition regardless of burning or grazing. It should be noted that any significant differences between ungrazed and grazed treatments in 1976 and 1978 were the result of natural variation and not the result of grazing, since cattle were not placed in the test pastures until May 1979.

Mature slash and longleaf pine crowns averaged $62 \%$ crown cover at the time of initial measurements in 1976. Hardwood tree species contributed little cover. With burning, most of the hardwood trees and shrubs were topkilled to ground-line but usually resprouted. Conditions were similar in both grazed and ungrazed treatments. Natural regeneration of pines under this mature canopy, however, was minimal.

Saw-palmetto and gallberry were the dominant shrubs prior to and following treatment (Table 3). Burning in February of 1978 and 1981 reduced saw-palmetto and gallberry foliar coverage in those years but, at the end of the study, coverage slightly exceeded initial estimates in both ungrazed and grazed conditions. Huckleberry (Gaylussacia spp.) and runner oaks [Quercus pumila Walt., Q. minima (Sarg.) Small] initially were the next most important shrubs, and they held similar positions at the end of the study. Practically all shrubby species reacted to fire with reductions occurring during the year of burning but recovery in the following years. The only species that seemed intolerant of burning were dwarf pawpaw [Asimina parviflora (Michx.) Dunal] and St. John's wort (Hypericum spp.).

Vines were a minor component of the understory woody coverage throughout the study. Muscadine grape (Vitis rotundifolia Michx.) and greenbriers (Smilax spp.) were the most common and are known to provide important wildlife food resources in the form of fruit and browse (Harlow and Jones 1965). Vines responded to fire in a manner similar to that of shrubs: they decreased the year of burning with a gradual increase in cover between the fires.

The responses of woody species in these natural stands to periodic prescribed burning in the winter were similar to Langdon's (1981) report of plant persistence but reduction in size and crown coverage after 30 years of repeated burning. Reduction of woody plant cover due to livestock browsing apparently was not a significant factor. Kalmbacher et al. (1984) reported diets of cattle on the south Florida range to be composed of 9 and $26 \%$ browse in summer and winter, respectively.

\section{Herbaceous Plants}

The most common herbaceous plants were pineland threeawn (Aristida stricta Michx.), grassleaf goldaster [Heterotheca graminifolia (Michx.) Shinners], and bracken fern [Pteridium aquillinum (L.) Kuhn.] (Table 2). Several species noticeably increased following introduction of fire, eg., sensitive partridgepea (Cassia nictitans L.) (the most common legume), eupatorium (Eupatorium spp.), and low-panicums (Dichanthelium spp.). Others that responded positively, probably more from increases in plant size rather than new plants, were pineland threeawn and creeping bluestem (Schizachyrium stoloniferum Nash).

Grazing had little negative effect on plant frequencies of occurrence. The low-panicum grasses continued to increase with grazing and following burning. Bracken fern was less frequent in grazed as compared to ungrazed pastures, but this seemed to be the result of an initially low frequency of occurrence rather than a response to grazing. In 1981 eupatoriums, legumes, and other forbs were signif- 
Table 2. Frequency of occurrence of herbaceous plants and cover by woody vegetation in pastures with an overstory of s0-year-old slash and longleaf pines and an understory that was preseribed burned in February 1978 and 1981 . Data collected in September and October of year indicated.1

\begin{tabular}{|c|c|c|c|c|c|c|c|c|c|c|}
\hline \multirow[b]{2}{*}{ Plant type and species } & \multicolumn{5}{|c|}{ Ungrazed pastures } & \multicolumn{5}{|c|}{ Grazed pastures 2} \\
\hline & 1976 & 1978 & 1980 & 1981 & 1983 & 1976 & 1978 & 1980 & 1981 & 1983 \\
\hline Shrubs & & & & & $-f$ & - & & & & - \\
\hline $\begin{array}{l}\text { Gaylussacia spp. } \\
\text { Ilex glabra (L.) Gray } \\
\text { Lyonia lucida (Lam.) K. Koch } \\
\text { Myrica cerifera L. } \\
\text { Quercus minima, pumila Walt. } \\
\text { Rubus spp. } \\
\text { Serenoa repens (Bartr.) Small } \\
\text { Vaccinium myrsinites Lam. } \\
\text { Other shrubs }\end{array}$ & $\begin{array}{r}5.1 \\
10.2 \\
2.6 \\
1.6 \\
7.1 \\
2.5^{*} \\
20.5 \\
3.9 \\
6.9 *\end{array}$ & $\begin{array}{l}2.2 \\
2.0 \\
0.6 \\
0.5 \\
4.0 \\
0.6^{*} \\
6.1 \\
1.1 \\
3.5\end{array}$ & $\begin{array}{r}9.9 \\
12.8 \\
6.6 \\
2.9 \\
7.9 \\
0.8^{*} \\
21.2 \\
5.3 \\
19.3\end{array}$ & $\begin{array}{c}8.5 \\
8.4 \\
3.1 \\
2.0 \\
11.5 \\
0.7^{*} \\
19.9 \\
3.0 \\
15.1^{*}\end{array}$ & $\begin{array}{c}1.4 \\
11.6 \\
4.5 \\
2.1 \\
7.5 \\
0.5 * \\
22.8 \\
4.9 \\
16.0\end{array}$ & $\begin{array}{r}6.4 \\
17.0 \\
0.6 \\
0.4 \\
5.7 \\
0.4 \\
31.9 \\
5.4 \\
1.9\end{array}$ & $\begin{array}{l}3.2 \\
4.4 \\
0.1 \\
0.2 \\
2.2 \\
0.1 \\
7.8 \\
1.7 \\
0.6\end{array}$ & $\begin{array}{r}12.8 \\
19.8 \\
1.6 \\
0.6 \\
5.6 \\
0.1 \\
30.8 \\
7.8 \\
3.1\end{array}$ & $\begin{array}{r}11.8 \\
12.2 \\
1.0 \\
1.0 \\
9.2 \\
0.1 \\
25.0 \\
0.6 \\
1.3\end{array}$ & $\begin{array}{r}5.3 \\
25.2^{*} \\
1.4 \\
1.3 \\
5.0 \\
0.1 \\
31.8 \\
8.0 \\
2.9\end{array}$ \\
\hline $\begin{array}{l}\text { Vines } \\
\text { Smilax rotundifolia } \mathrm{L} \text {. } \\
\text { Vitis rotundifolia } \mathrm{Michx} \text {. } \\
\text { Other vines }\end{array}$ & $\begin{array}{l}1.1 \\
0.0 \\
0.0\end{array}$ & $\begin{array}{l}0.2 \\
0.0 \\
0.0\end{array}$ & $\begin{array}{l}1.1 \\
0.0 \\
0.2\end{array}$ & $\begin{array}{l}1.0 \\
0.0 \\
0.1\end{array}$ & $\begin{array}{r}1.2 \\
0.0 \\
<0.1\end{array}$ & $\begin{array}{l}0.2 \\
3.6 \\
1.8\end{array}$ & $\begin{array}{l}0.1 \\
0.8 \\
0.4\end{array}$ & $\begin{array}{l}0.2 \\
3.0 \\
3.9\end{array}$ & $\begin{array}{l}0.3 \\
0.8 \\
1.0\end{array}$ & $\begin{array}{l}0.2 \\
0.6 \\
2.2\end{array}$ \\
\hline $\begin{array}{l}\text { Trees } \\
\text { Pinus elliottii Engelm. } \\
\text { Pinus spp. } \\
\text { Quercus nigra L. } \\
\text { Quercus spp. } \\
\text { Other trees }\end{array}$ & $\begin{array}{c}<0.1 \\
58.2 \\
0.0 \\
2.1^{*} \\
0.2\end{array}$ & $\begin{array}{l}0.0 \\
0.0 \\
0.0 \\
0.0\end{array}$ & $\begin{array}{r}0.0 \\
0.2 \\
<0.1 \\
0.3\end{array}$ & $\begin{array}{r}0.0 \\
0.0 \\
<0.1 \\
0.4\end{array}$ & $\begin{array}{r}0.0 \\
0.0 \\
<0.1 \\
0.7\end{array}$ & $\begin{array}{r}0.0 \\
65.0 \\
0.4 \\
0.3 \\
1.6\end{array}$ & $\begin{array}{l}0.0 \\
0.1 \\
0.1 \\
0.4\end{array}$ & $\begin{array}{l}0.0 \\
-1 \\
0.4 \\
0.0 \\
1.9\end{array}$ & $\begin{array}{l}<0.1 \\
--0 \\
0.0 \\
0.2 \\
2.0\end{array}$ & $\begin{array}{r}<0.1 \\
0.2 \\
0.2 \\
2.7\end{array}$ \\
\hline
\end{tabular}

Grasses

\begin{tabular}{|c|c|c|c|c|c|c|c|c|c|c|}
\hline Andropogon capillipes Nash & 0.3 & 0.0 & 0.8 & 0.5 & 1.0 & 1.6 & 1.1 & 1.6 & 1.1 & 1.6 \\
\hline Andropogon virginicus $\mathrm{L}$. & 1.3 & 2.0 & 3.8 & 3.0 & 3.8 & 3.8 & 3.2 & 5.8 & 1.9 & 6.6 \\
\hline Aristida stricta Michx. & 17.2 & 19.7 & 26.8 & 20.3 & 24.3 & 7.9 & 16.8 & 19.6 & 18.3 & 20.0 \\
\hline Dichanthelium spp. & 0.0 & 2.8 & 4.3 & 4.7 & 4.5 & 0.0 & 3.6 & 7.5 & 6.0 & 8.0 \\
\hline Panicum spp. & 2.3 & 0.3 & 3.9 & 0.5 & 0.8 & 2.9 & 0.2 & 4.0 & 1.4 & 0.0 \\
\hline Panicum verrucosum Muhl. & 0.0 & 0.0 & 0.0 & 0.0 & 0.0 & 0.0 & 0.1 & 0.0 & 0.4 & 0.0 \\
\hline Paspalum setaceum Michx. & 0.0 & 1.0 & 0.5 & 0.0 & 0.0 & 0.0 & 0.5 & 0.4 & 0.2 & 0.0 \\
\hline Schizachyrium stoloniferum & & & & & & & & & & \\
\hline Nash & 0.3 & 2.2 & 1.8 & 2.8 & 1.3 & 0.7 & 2.5 & 1.0 & 1.9 & 1.0 \\
\hline Other grasses & 4.4 & 4.6 & 8.3 & 7.3 & 7.4 & 5.9 & 3.6 & 3.1 & 4.3 & 2.8 \\
\hline rass-likes & & & & & & & & & & \\
\hline Cyperus spp. & 0.3 & 0.3 & 0.0 & 0.2 & 0.0 & 0.1 & 0.5 & 0.0 & 0.0 & 0.0 \\
\hline Rhynchospora spp. & 0.0 & 0.2 & 0.0 & 0.5 & 0.5 & 0.0 & 2.3 & 1.2 & 0.4 & 0.1 \\
\hline Scleria spp. & 1.8 & 2.3 & 2.2 & 2.8 & 2.0 & 1.9 & 2.2 & 1.5 & 1.8 & 2.4 \\
\hline Other grass-likes & 0.2 & 1.3 & 0.8 & 0.5 & 0.0 & 1.0 & 1.3 & 1.2 & 0.8 & 0.0 \\
\hline orbs & & & & & & & & & & \\
\hline Aster spp. & 0.0 & 1.5 & 0.7 & 1.3 & 0.9 & $2.8^{*}$ & 0.8 & 0.9 & 1.2 & 0.8 \\
\hline Diodia teres Walter & 0.0 & 0.5 & 0.0 & 0.0 & 0.0 & 0.0 & 0.2 & 0.0 & 0.0 & 0.0 \\
\hline Eupatorium spp. & 0.0 & 2.4 & 0.7 & $2.0^{*}$ & 0.2 & 0.0 & 2.5 & 0.0 & 0.2 & 0.0 \\
\hline Heterotheca graminifolia & & & & & & & & & & \\
\hline (Michx.) Shinners & 9.2 & 5.3 & 10.5 & 10.0 & 19.8 & 3.1 & 5.2 & 6.5 & 6.8 & 7.7 \\
\hline Legumes (Fabaceae) & 3.9 & 6.3 & 0.5 & $6.6^{*}$ & 0.2 & 0.9 & 3.2 & 0.5 & 1.5 & 0.1 \\
\hline Rhexia spp. & 0.7 & 0.2 & 0.6 & 0.5 & 0.0 & 1.4 & 0.9 & 0.2 & 0.6 & 0.1 \\
\hline Xyris spp. & 0.0 & 0.0 & 0.0 & 0.0 & 0.0 & 0.2 & 0.0 & 0.5 & 0.2 & 0.1 \\
\hline Other forbs & 1.1 & 6.4 & 5.5 & $4.8^{*}$ & 4.8 & 0.8 & 2.7 & 3.0 & 1.9 & 1.5 \\
\hline & & & & & & & & & & \\
\hline Pteridium aquilinum (L.) Kuhn & $37.5^{*}$ & $47.0^{*}$ & $28.3^{*}$ & $44.0^{*}$ & $26.0^{*}$ & 6.2 & 6.2 & 2.6 & 4.8 & 6.2 \\
\hline Other ferns & 0.0 & 0.3 & 0.8 & 0.8 & 0.0 & 1.1 & 2.4 & 2.1 & 3.6 & 2.8 \\
\hline
\end{tabular}

Values for ungrazed treatments are averages from two pastures while values for grazed are averages from 4 pastures with 3 line-transects in each. Means marked with an asterisk are significantly larger than the corresponding mean for that year in the other grazed treatment.

2Livestock grazing did not begin until 1979.

${ }^{3}$ Canopy coverage by 50-year-old longleaf and slash pines was estimated only in 1976 because treatments had no effect on pine canopy.

icantly more frequent in ungrazed pastures but not in 1980 nor 1983 , the other years when cattle grazed the pastures. Since 1981 was extremely dry during the spring, these species may have been grazed more heavily than in other years.

\section{Harvested and Site Prepared Stands Woody Plants}

Trees, other than pines, did not initially contribute much cover- age (Table 3). Overstory harvest and site preparation almost eliminated all woody cover, but the surviving individuals began a slow recovery. Water oak (Quercus nigra L.) seemed to recover most quickly. Planted slash pine eventually provided the greatest coverage among tree species. Naturally regenerating longleaf pine occurred in both grazed and ungrazed pastures. By the end of the study, tree canopy was dominated by pines and oaks. 
Table 3. Frequency of occurrence of herbaceous plants and cover by woody vegetation in pastures that were clearcut and double-chopped in 1977; averages of planted and unplanted pastures. Data collected in September and October of year indicated.1

\begin{tabular}{|c|c|c|c|c|c|c|c|c|c|c|}
\hline \multirow[b]{2}{*}{ Plant type and species } & \multicolumn{5}{|c|}{ Ungrazed pastures } & \multicolumn{5}{|c|}{ Grazed pastures $^{2}$} \\
\hline & 1976 & 1978 & 1980 & 1981 & 1983 & 1976 & 1978 & 1980 & 1981 & 1983 \\
\hline Shrubs & & & & & -foli & - & & & & - \\
\hline $\begin{array}{l}\text { Gaylussacia spp. } \\
\text { llex glabra (L.) Gray } \\
\text { Lyonia lucida (Lam.) K. Koch } \\
\text { Myrica cerifera L. } \\
\text { Quercus minima, pumlla Walt. } \\
\text { Rubus spp. } \\
\text { Serenoa repens (Bartr.) Small } \\
\text { Vaccinium myrsinites Lam. } \\
\text { Other shrubs }\end{array}$ & $\begin{array}{r}5.4 \\
10.6 \\
0.6 \\
0.7 \\
3.3 \\
0.3 \\
31.6 \\
1.4 \\
2.7\end{array}$ & $\begin{array}{l}0.7^{*} \\
0.9 \\
0.4 \\
<0.1 \\
0.5 \\
1.0^{*} \\
1.5 \\
0.3 \\
2.1\end{array}$ & $\begin{array}{l}4.3 \\
9.0 \\
1.2 \\
2.1 \\
2.4 \\
5.2 \\
7.4 \\
1.9 \\
6.0^{*}\end{array}$ & $\begin{array}{r}6.6^{*} \\
10.6 \\
1.7 \\
3.5 \\
2.3 \\
4.3 \\
8.9 \\
1.8 \\
2.9\end{array}$ & $\begin{array}{r}2.0 \\
19.0 \\
1.8 \\
7.0 \\
1.3 \\
4.6 \\
12.9 \\
2.1 \\
2.1 \\
2.8\end{array}$ & $\begin{array}{r}4.4 \\
12.7 \\
1.7 \\
0.6 \\
2.5 \\
0.1 \\
27.2 \\
1.9 \\
4.6\end{array}$ & $\begin{array}{l}0.4 \\
0.9 \\
1.1 \\
0.1 \\
0.4 \\
0.4 \\
1.0 \\
0.2 \\
2.0\end{array}$ & $\begin{array}{r}2.8 \\
10.4 \\
3.8 \\
2.6 \\
2.1 \\
5.3 \\
6.8 \\
1.5 \\
5.4\end{array}$ & $\begin{array}{l}2.3 \\
9.6 \\
5.1 \\
3.5 \\
1.7 \\
5.8 \\
7.4 \\
1.2 \\
4.4\end{array}$ & $\begin{array}{r}1.0 \\
16.4 \\
3.3 \\
6.7 \\
1.8 \\
3.7 \\
10.7 \\
1.6 \\
4.3\end{array}$ \\
\hline $\begin{array}{l}\text { Vines } \\
\text { Smilax rotundifolia L. } \\
\text { Vitis rotundifolia Michx. } \\
\text { Other vines }\end{array}$ & $\begin{array}{l}0.2 \\
2.9 \\
0.6\end{array}$ & $\begin{array}{r}0.2 \\
0.1 \\
<0.1\end{array}$ & $\begin{array}{l}0.7 \\
0.4 \\
2.4\end{array}$ & $\begin{array}{l}0.6 \\
0.1 \\
2.3\end{array}$ & $\begin{array}{l}0.5 \\
0.2 \\
3.3\end{array}$ & $\begin{array}{l}0.9 \\
2.3 \\
2.0\end{array}$ & $\begin{array}{l}0.8 \\
0.2 \\
0.1\end{array}$ & $\begin{array}{l}2.0 \\
0.6 \\
4.1\end{array}$ & $\begin{array}{l}1.7 \\
0.6 \\
4.7\end{array}$ & $\begin{array}{l}2.0 \\
0.9 \\
8.7\end{array}$ \\
\hline $\begin{array}{l}\text { Trees } \\
\text { Pinus elliottii Engelm. } \\
\text { Pinus spp. }{ }^{3} \\
\text { Quercus nigra L. } \\
\text { Quercus spp. } \\
\text { Other trees }\end{array}$ & $\begin{array}{r}0.0 \\
65.4 \\
7.2 \\
1.6^{*} \\
3.3\end{array}$ & $\begin{array}{l}0.1 \\
0.4 \\
0.0 \\
0.1\end{array}$ & $\begin{array}{c}4.3^{*} \\
3.4 \\
1.0 \\
2.3\end{array}$ & $\begin{array}{l}6.2 \\
2.6 \\
0.7 \\
2.9\end{array}$ & $\begin{array}{l}14.8 \\
8.0 \\
0.8 \\
5.9\end{array}$ & $\begin{array}{r}0.0 \\
59.3 \\
4.5 \\
0.1 \\
3.1\end{array}$ & $\begin{array}{l}0.1 \\
0.2 \\
0.1 \\
0.6\end{array}$ & $\begin{array}{l}2.6 \\
1.5 \\
0.5 \\
2.6\end{array}$ & $\begin{array}{l}4.7 \\
2.2 \\
1.3 \\
2.6\end{array}$ & $\begin{array}{r}13.4 \\
4.9 \\
1.1 \\
4.2\end{array}$ \\
\hline
\end{tabular}

Grasses

\begin{tabular}{|c|c|c|c|c|c|c|c|c|c|c|}
\hline \\
\hline Andropogon capillipes Nash & 0.4 & 5.3 & 43.2 & 46.1 & 44.3 & 0.3 & 3.2 & 10.8 & 34.4 & 30.1 \\
\hline Andropogon virginicus $\mathrm{L}$. & 0.5 & 3.1 & 15.6 & 12.7 & 10.3 & 1.9 & 1.9 & 23.4 & $20.6^{*}$ & $20.7 *$ \\
\hline Aristida stricta Michx. & 8.3 & 5.3 & 9.2 & 11.2 & 13.7 & 7.7 & 2.7 & 4.7 & 6.6 & 10.1 \\
\hline Dichanthelium spp. & 0.0 & 44.9 & 7.1 & 16.1 & 14.5 & 0.0 & $55.9^{*}$ & $25.4^{*}$ & $39.6^{*}$ & $37.9 *$ \\
\hline Panicum spp. & 0.2 & 14.0 & 19.0 & 3.3 & 7.1 & 1.0 & 23.0 & 20.0 & 14.8 & 13.5 \\
\hline Panicum verrucosum Muhl. & 0.0 & 8.3 & 1.0 & 0.3 & 0.0 & 0.0 & 8.2 & 2.8 & 2.1 & 0.0 \\
\hline Paspalum setaceum Michx. & 0.1 & 2.6 & 2.1 & 2.7 & 0.8 & 0.0 & 3.5 & 4.4 & 2.5 & 0.3 \\
\hline Schizachyrium stoloniferum & & & & & & & & & & \\
\hline Nash & 1.2 & 0.6 & 1.8 & 4.4 & $4.7^{*}$ & 0.3 & 0.7 & 1.1 & 2.0 & 1.3 \\
\hline Other grasses & 2.1 & 5.0 & 6.4 & 5.4 & 6.7 & 3.7 & 4.3 & 9.7 & 7.7 & 8.4 \\
\hline Jrass-Likes & & & & & & & & & & \\
\hline Cyperus spp. & 0.4 & 11.4 & 0.2 & 0.8 & 0.0 & 0.3 & 6.9 & 2.7 & 1.4 & 0.3 \\
\hline Rhychospora spp. & 0.0 & 9.2 & 4.8 & 1.1 & 0.2 & 0.0 & 8.7 & 7.2 & 3.1 & $3.6 *$ \\
\hline Scleria spp. & 0.5 & 7.9 & 5.1 & 4.5 & 5.2 & 0.9 & 13.6 & 9.4 & 7.7 & 6.7 \\
\hline Other grass-likes & 0.3 & 9.3 & 3.3 & 1.2 & 1.1 & 2.5 & 7.5 & 5.0 & 3.2 & 2.2 \\
\hline Corbs & & & & & & & & & & \\
\hline Aster spp. & 2.0 & 1.4 & 3.6 & 1.7 & 1.4 & 4.5 & 1.2 & 1.7 & 0.9 & 1.5 \\
\hline Diodia teres Walter & 0.3 & 17.6 & 1.1 & 0.4 & 0.1 & 0.0 & 18.7 & 1.3 & 0.2 & 0.1 \\
\hline Eupatorium spp. & 0.0 & 3.0 & 2.6 & 1.8 & 1.1 & 0.0 & 2.6 & 3.3 & 2.9 & 2.1 \\
\hline Heterotheca graminifolia & & & & & & & & & & \\
\hline (Michx.) Shinners & 3.4 & 4.2 & 6.8 & 6.0 & $14.1 *$ & 2.0 & 1.5 & 3.2 & 2.4 & 5.0 \\
\hline Legumes (Fabaceae) & 0.5 & 3.4 & 1.1 & 1.1 & 0.1 & 2.4 & 4.7 & 2.3 & 1.1 & 0.8 \\
\hline Rhexia spp. & 0.4 & 1.7 & 3.3 & 2.8 & 0.3 & 0.1 & 1.2 & 5.3 & 5.6 & 0.5 \\
\hline Xyris spp. & 0.3 & 3.6 & 2.5 & 4.2 & 1.7 & 0.5 & 2.6 & 5.2 & 3.2 & 1.2 \\
\hline Other forbs & 1.1 & 11.6 & 11.3 & 7.1 & 4.8 & 2.6 & 3.7 & 17.9 & 12.5 & $9.6^{*}$ \\
\hline Frns & & & & & & & & & & \\
\hline Pteridium aquilinum (L.) Kuhn & 21.4 & 27.0 & 17.8 & 22.9 & 23.4 & 17.2 & 25.4 & 17.8 & 19.9 & 18.6 \\
\hline Other ferns & 1.4 & 1.4 & 1.1 & 1.7 & 2.6 & 1.7 & 1.7 & 2.4 & 2.0 & 1.1 \\
\hline
\end{tabular}

'Values for ungrazed treatments are averages from 6 pastures while values for grazed are averages from 16 pastures with 3 line-transects in each. Means marked with an asterisk are significantly larger than the corresponding mean for that year in the other grazed condition.

2Livestock grazing did not begin until 1979.

${ }^{3}$ Canopy coverage by 50-year-old longleaf and slash pines was estimated only in 1976.

Saw-palmetto, the dominant shrub prior to treatment, was greatly reduced by double-chopping. However, surviving sawpalmetto plants increased in cover annually, but still provided less than half the original cover after 6 years. Runner oak and huckleberry were reduced by chopping and, like saw-palmetto, never regained their former degree of cover. Gallberry, the second most dominant shrub, was reduced by chopping but recovered rapidly. This plant root-sprouts prolifically on chopped areas and, thereby, provided greater coverage at the end of study than initially. Blackberry (Rubus spp.), fetterbush [Lyonia lucida (Lam.) K. Koch], and southern waxmyrtle (Myrica cerifera L.), species that generally increase with disturbance, had greater coverage at the end than at the beginning of study. Most of the minor shrubs remained unchanged after the initial reduction from chopping.

Before treatment, muscadine grape had greater foliar cover than all other vines. Reductions in vine coverage with disturbance was 
followed by some increases for most species. Greatest recovery was by other vines, which were primarily yellow jessamine [Gelsemium sempervirens (L.) Aiton f.], a species poisonous to livestock. Grape, greenbrier, and yellow jessamine are known to be preferred foods for white-tailed deer (Harlow and Jones 1965).

The responses of woody plants to mechanical disturbance by clearcutting and chopping were similar to those reported by Conde et al. (1983) on a similar site. Most species persisted and began to regain canopy cover over time following the initial reduction from chopping. In south Florida, similar trends were noted, especially for saw-palmetto (Lewis 1970, Moore 1974, Tanner et al. 1988).

Grazing tended to reduce the cover of some shrubs such as ground blueberry (Vaccinium myrsinites Lam.), runner oak, and saw-palmetto, but the only statistically significant reduction was on huckleberry in 1981. Although cattle will browse on shrubs (Kalmbacher et al. 1984) and young hardwoods, they usually do not contribute much to cattle diets. Thill (1984) found very few woody plant species to comprise more than $5 \%$ of both cattle and deer diets on Louisiana pine-hardwood sites.

\section{Herbaceous Plants}

Pretreatment measurements indicated that pineland threeawn, grassleaf goldaster, and bracken fern were the most common herbaceous plants in the understory on these pastures (Table 3), similar to the previously discussed natural tree stands. Following clearcutting and site preparation, a heavy influx of new herbaceous species was measured, particularly among the forbs and grasslikes. Many species, such as eupatorium persisted throughout the study, particularly where grazing kept a more open condition. After an increase immediately following disturbance, a trend toward decreasing occurrence was apparent in legumes, flatsedge (Cyperus spp.), maidenhair sedge (Eleocharis vivipara Link), sloughgrass (Scleria spp.), poor joe (Diodia teres Walter), and eupatorium similar to old-field succession. Although grassleaf goldaster maintained its frequency of occurrence under grazing, it increased in ungrazed pastures to a level of being significantly greater than in grazed pastuires after 6 years. Occurrence of other forbs decreased after the initial surge following disturbance and no grazing, while occurrence in grazed pastures remained high and significantly greater in 1983. Rhynchospora (Rhynchospora spp.) responded in a similar manner. Bracken fern remained quite constant following site disturbance and was not affected by grazing.

Grasses, such as chalky bluestem (Andropogon capillipes Nash), broomsedge bluestem (Andropogon virginicus L.), and lowpanicums that are important foods for cattle, increased greatly following mechanical disturbance. Responses in both ungrazed and grazed pastures were similar initially and little harmful impact after grazing began in 1979 was observable on most species. Broomsedge and low-panicums continued to increase and attained significantly higher amounts with grazing. Occurrence of creeping bluestem, a very desirable cattle food, typically is stimulated by site disturbance associated with chopping (Yarlett 1965). In this study creeping bluestem occurrence also increased and was significantly greater in ungrazed than in grazed pastures by the end of the study.

Pineland threeawn is a relatively undesirable forage grass because of its low nutrient content and poor digestibility (Lewis et al. 1975). This plant suffers considerable mortality when chopped or disked but is seldom eliminated. Although pineland threeawn frequency of occurrence on site prepared areas was approximately one-half of natural stands, slow, but steady increases occurred throughout the study. Under the open, site prepared conditions, increases in crown spread of surviving plants accounted for its increase in occurrence through time.

\section{Planted Pine Responses to Grazing}

Grazing per se and deferred-rotation treatments had no significant influence on any of the parameters measured on planted pines through age 5. Although survival was significantly less in pastures
Table 4. Influence of graxing treatments on average survival, beight, diameter (DBH), height to first living limb (crown base), and crown diameter of planted slash pine after 6 growing seasons. Graxing began in May of the second growing season.!

\begin{tabular}{lccccc}
\hline \hline $\begin{array}{l}\text { Grazing } \\
\text { treatment }\end{array}$ & Survival & Height & Diameter & $\begin{array}{c}\text { Crown } \\
\text { base }\end{array}$ & $\begin{array}{c}\text { Crown } \\
\text { diameter }\end{array}$ \\
\hline & $-\%-$ & $-\mathrm{m}-$ & $-\mathrm{cm}-$ & $-\mathrm{m}--$ & $-\mathrm{m}--$ \\
$0-12$ & $91^{\mathrm{a}}$ & 4.1 & 6.1 & 1.2 & 1.5 \\
$30-4$ & $92^{\mathrm{a}}$ & 4.3 & 7.0 & 1.1 & 1.7 \\
$30-6$ & $96^{\mathrm{a}}$ & 3.9 & 5.8 & 1.3 & 1.4 \\
$45-3$ & $80^{\mathrm{b}}$ & 4.0 & 6.3 & 1.2 & 1.5 \\
\hline
\end{tabular}

'Means within a column for any age that are marked with differing superscripts are significantly different at the 0.05 level. Unmarked means are not significantly different.

2The deferred-rotation grazing treatments are identified by the number of days grazed followed by the number of months rested before being grazed again, e.g., $30-4$ indicates a 3-day grazing period followed by 4-months rest.

grazed for $\mathbf{4 5}$ days and rested for 3 months following the 6th growing season (Table 4), the additional mortality of trees that year was not caused by cattle. Rather, these tree deaths were caused by permanent stunting after $80 \%$ needle defoliation by an unknown insect during the second growing season and by suppression from a dense stand of over-topping brush, primarily gallberry.

Tree growth was not affected in any year by any deferredrotation grazing treatment (Table 4). Heights averaged $4.1 \mathrm{~m}$ at plantation age 6 while diameters averaged $6.3 \mathrm{~cm}$. These growth rates were similar to other plantations on flatwood sites of this region (Lewis et al. 1985). Also, crown development was not affected by grazing treatments. Although cattle sometimes break lower limbs by rubbing on stems, this did not change the height to the lowest living branch. At the end of the 4th growing season, when pines were at a height to be particularly susceptible to this form of injury, only $0.2 \%$ of the trees were noted to have limb breakage, $0.9 \%$ were leaning due to rubbing attributed to cattle, and $0.2 \%$ had partial girdling of the stem from hoof action. During the 6 th year, the only other year with cattle-related damage, $0.2 \%$ were found to be leaning from rubbing. Although limb breakage could influence crown spread, crown diameters were similar on grazed and ungrazed treatments in all years.

Injury to planted pines can come from several sources: fire, animals, insects, and diseases. Insects were the primary form of injury in this study: pine tipmoth (Rhyacionia spp.) were active in the early years infesting $14.1,2.3$, and $0.2 \%$ of the trees during the 2nd, 3rd, and 4th seasons, respectively. Southern fusiform rust [Cronartium quercum (Berk.) Miyabe ex Shirai f. sp. fusiforme (Burdsall and Snow)] was noted on $0.7 \%$ of the trees after the 4 th season and had increased to $5.1 \%$ during the 6th season. Pitch canker (Fusarium moniliforme Sheld. var. subglutinans Wollenw. and Reink.) had infested $1.6 \%$ of the trees during the 6 th season. Overall, cattle were a minor source of injury to the pines and probably did not affect survival or growth considering the minor amount or type of injury (Lewis 1980a, 1980b).

Overall, planting pines in double-rows with wide spaces between, as compared to the normal, single-row configuration, did not influence tree growth. Although height to the first living branch was significantly greater for pines planted in single rows after 3 growing seasons, differences were not significant in other years. These responses to planting configuration follow those of other studies reported by Lewis et al. (1985).

\section{Conclusions}

Site preparation for planting pines is intended to reduce early competition to assure good establishment and rapid early growth. Since neither burning, clearcutting and site preparing, not grazing had a major or lasting affect on species composition and foliar cover of most woody plants, these management practices can be 
continued in the pine flatwoods without harmful effects on these components of the environment.

Reintroduction of prescribed burning within natural stands increased the occurrence of most grasses and forbs and allowed new species to occur. Periodic fire helped maintain the presence of most species and, therefore, is recognized as being desirable for maintaining a vigorous, diverse understory for forage and wildlife habitat.

With mechanical disturbance, many new herbaceous species appeared and most other species increased in occurrence, while pineland threeawn decreased. The general trend of most plants was to increase immediately following disturbance and then to slowly decrease over time as ecological succession proceeded. However, some very desirable forage species persisted or increased, which resulted in an improved herbaceous strata for livestock grazing. Lewis et al. (1984) reported an increase in forage yields following site preparation.

Planted slash pine had little influence on occurrence of herbaceous species through plantation age 6 years. However, crown closure was incomplete in all stands, especially in the double-row configuration. In contrast, both tree and brush canopies tended to keep occurrence of herbaceous species low in the natural stands. The biggest changes resulted from tree harvest and site preparation which initially removed most woody plants. Their gradual return was accompanied by declines in some herbaceous species. These successional trends are explored more fully in a companion article (Lewis et al. 1988).

Compared to ungrazed areas, the effect of these deferredrotation grazing systems exerted little influence on most herbaceous species. Apparently, the rest periods following grazing allowed most species to maintain a satisfactory level of vigor. Also, trampling disturbance of the soil and keeping the understory more open through removal of plant material by cattle may maintain more species than occurs with total protection from grazing. In ungrazed treatments, the lack of defoliation by grazing or prescribed fire appeared to cause some species to stagnate and decline in vigor.

This integrated pine-cattle management study shows that multiple products can be simultaneously produced without major impact on each other. This lends validity to conclusions drawn from synthesis efforts to evaluate combining cattle, timber, and wildlife management. It appears that neither site preparation, burning, nor proper grazing has an extremely harmful nor longlasting effect on woody and herbaceous species or on planted slash pine. Regulating grazing intensity and reducing pine density or crown coverage through planting configuration will maintain good forage resources, wildlife habitat, and wood yields.

\section{Literature Cited}

Conde, L.F., B.F. Swindel, and J.E. Smith. 1983. Plant species cover, frequency, and biomass: Early responses to clearcutting, chopping, and bedding in Pinus elliottii flatwoods. Forest Ecol. Manage. 6:307-317.

Grelen, H.E., L.B. Whitaker, and R.E. Lohrey. 1972. Herbage response to precommercial thinning in direct-seeded slash pine. J. Range Manage. 25:435-437.
Halls, L.K., O.M. Hale, and B.L. Southwell. 1956. Grazing capacity of wiregrass-pine ranges of Georgia. Georgia Agr. Exp. Sta. Tech. Bull. N.S. 2. $38 \mathrm{p}$.

Harlow, R.F., and F.K. Jones. 1965. The white-tailed deer in Florida. Fla. Game and Fresh Water Fish Comm. Tech. Bull. No. 9. 240 pp.

Hilmon, J.B., C.E. Lewis, and J.E. Bethune. 1962. Highlights of recent results of range research in southern Florida. Proc. Soc. Amer. Forest. 1962:73-76.

Kalmbacher, R.S., K.R. Long, M.K. Johnson, and F.G. Martin. 1984. Botanical composition of diets of cattle grazing south Florida range. $J$. Range Manage. 37:334-340.

Langdon, 0.G. 1981. Some effects of prescribed fire on understory in loblolly pine stands. P. 143-153. In: Prescribed Fire and Wildlife in Southern Forests Symp. Proc. Clemson Univ.

Lewis, C.E. 1970. Responses to chopping and rock phosphate on south Florida ranges. J. Range Manage. 23:276-282.

Lewis, C.E. 1980a. Simulated cattle injury to planted slash pine: Combinations of defoliation, browsing, and trampling. J. Range Manage. 33:340-345.

Lewis, C.E. 1980b. Simulated cattle injury to planted slash pine: Girdling. J. Range Manage. 33:337-340.

Lewis, C.E. 1973. Integrating management of forest and range resources. P. 69-78. In: Range Resources of the Southeastern United States. Amer. Soc. Agron. Spec. Pub. 21.

Lewis, C.E. 1975. Grazing considerations in managing young pines. P. 160-170. In: Management of Young Pines Symp. Proc., 1974. USDA Forest Serv., Southern and Southeastern Forest Exp. Sta. and Southern Area State and Private Forestry.

Lewis, C.E. 1977. Principles and status of integrated management from the range viewpoint. P. 26-34 In: Mutual Opportunities for Forest, Range, Wildlife Management Symp. Sch. Forest Resour. and Conserv. Rep. 4.

Lewis, C.E., R.S. Lowrey, W.G. Monson, and F.E. Knox. 1975. Seasonal trends in nutrients and cattle digestibility of forage on pine-wiregrass range. J. Anim. Sci. 41:208-212.

Lewis, C.E., B.F. Swindel, L.F. Conde, and J.E. Smith. 1984. Forage yields improved by site preparation in pine flatwoods of north Florida. South J. Appl. Forest. 8:181-185.

Lewis, C.E., B.F. Swindel, and G.W. Tanner. 1988. Species diversity: Concept, measurement, and application to timber and grazing measurement. J. Range Manage. 41:469-472.

Lewis, C.E., G.W. Tanner, and W.S. Terry. 1985. Double vs. single-row pine plantations for wood and forage production. South. J. Appl. Forest. 9:55-61.

Moore, W.H. 1974. Some effects of chopping saw-palmetto-pineland threeawn range in south Florida. J. Range Manage. 27:101-104.

Pearson, H.A. 1975. Range and wildlife opportunities. P. 19-27. In: Management of Young Pines Symp. Proc. USDA Forest Serv. Southern and Southeastern Forest Exp. Sta. and Southern Area State and Private Forestry.

Pearson, H.A. 1980. Livestock in multiple-use management of southern forest range. P. 75-88 In: Southern Forest Range and Pasture Symposium. Winrock Internat.

Pearson, H.A., L.B. Whitaker, and V.L. Duvall. 1971. Slash pine regeneration under regulated grazing. J. Forest. 69:744-746.

Tanner, G.W., W.S. Terry, and R.S. Kalmbacher. 1988. Mechanical brush control on south Florida ranges. J. Range Manage. 41:245-248.

Thill, R.E. 1984. Deer and cattle diets on Louisiana pine-hardwood sites. J. Wildl. Manage. 48:788-798.

Wolters, G.L. 1982. Longleaf and slash pine decreases herbage production and alters herbage composition. J. Range Manage. 35:761-763.

Yarlett, L.L. 1965. Control of saw palmetto and recovery of native grasses. J. Range Manage. 18:344-345. 